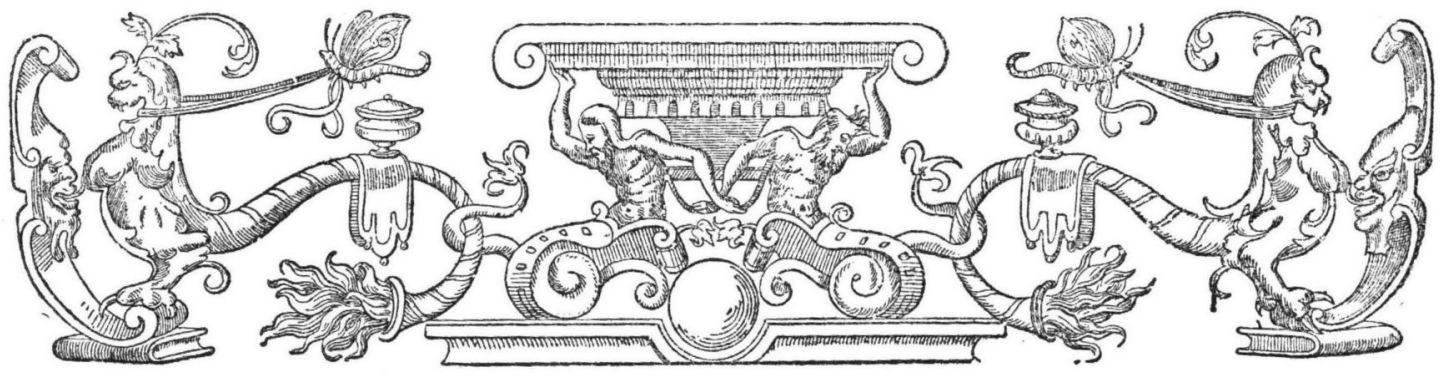

\title{
Constantijn Huygens en de Schilderkunst
}

DOOR

H. J. EYM A EL.

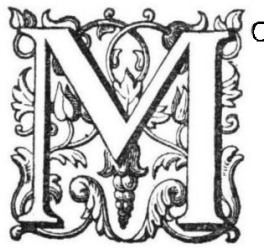

ORGEN is mijn dichter jarig" zong eenmaal een aankomend Muzenzoon en wijdde aan JACOB VAN LENNEP een lied vol geestdrift en bewondering. - "Morgen is mijn dichter driehonderajarig" zeg ik hem na, maar DE GENESTETs gouden veder is, helaas! niet in mijn schoot gevallén en van een lofzang ter eere van Constantijn Huygens kan dus bij mij geen sprake zijn. Trouwens, 't zou nog de vraag wezen, of die hem bijzonder aangenaam was. Eer- en klinkdichten zijn hem gedurende zijn leven zoo veelvuldig toegezongen, dat hij, naar mij dunkt, in de "zalige gewesten" er wel zijn bekomst van zal hebben. Aangenamer hulde meen ik hem dan ook op zijn feestdag te bewijzen, door in eenvoudig proza voor zijne eer als kunstenaar op te komen en de meening van mijn hooggeschatten vriend, Dr. A. S. KOK, te weerleggen, welke hem geringschatting van de schilders en hunne kunst te laste legt, een verwijt, dat den Dichter der "Korenbloemen", zoo hij althans nog acht slaat op het „werren" dezer ,werld", diep moet gegriefd hebben.

Dr. KoK, die zich op het gebied der vaderlandsche zoowel als op dat der vreemde letterkunde een welverdienden naam heeft verworven, geeft sinds eenigen Oud-Holland 1896. 
tijd in het bekende tijdschrift Noord en Zuid onder den bescheiden titel van Arenlezingen litterarische causerieën, welke de belezenheid en de kennis van hunnen auteur op iedere bladzijde staven en menige wetenswaardige bijzonderheid uit het leven en de werken van bekende schrijvers of aan de vergetelheid ontrukken, of in een nieuw daglicht stellen.

In no. 43 dezer reeks makkt hij, sprekende over bijschriften van dichters onder hunne portretten, ook van HuYGeNs gewag en zegt van enkele zijner gedichten, dat zij ,een niet zeer hoogen dunk geven van 's dichters hart en oog voor de schilderkunst"; ja, getuigt zelfs bij een hunner, dat er "zelden grooter gebrek aan waardeering ten opzichte der schilderkunst zoo driest is uitgesproken." Door Dr. WORP en mij op levensbijzonderheden en geschriften van HuYGENS gewezen, die het tegengestelde aantoonen, erkende Dr. KoK in $n^{\circ} .52$ ruiterlijk, dat er alle recht en reden tot een protest onzerzijds was gerveest, en dat, al zijn de door hem aangehaalde puntdichten niet weg te cijferen, de gevolgtrekking, die hij eruit had opgemaakt ten opzichte van HuYGENS' kunstliefde en kunstsmaak door hem moest teruggeromen worden. De zaak was dus weer in orde; doch daar wil een ongelukkig toeval, dat de schrijver de hand legt op nog enkele gedichten en brokstukken van gedichten, die hem weer aan het wankelen brengen, en waarin ,hem zulk een beslist tegenbewijs gegeven wordt, dat hij alle verdere gevolgtrekkingen aan den Lezer kan overlaten."

't $\mathrm{Zal}$ het doel dezer regelen zijn, mijn vriend KoK van dwaling te overtuigen en alzoo te verhoeden, dat de gevolgtrekkingen zijner lezers voor HUYGENS ongunstig zouden luiden.

Er is een bekend Fransch spreekwoord, dat zegt: "Donnez moi deux lignes d'écrit d'un homme et je le ferai pendre." Zonder het in de verste verte te willen, of zelfs te weten, heeft Dr. KOK zich van het daarin aangegeven recept bediend om HuyGeNs, wel niet op te hangen, maar hẹm toch als een minachter der edele schilderkunst aan de kaak te stellen. Inderdaad, wanneer men slechts enkele grepen doet in de uitingen van een schrijver en vooral van een dichter, d. i. een dikwijls onder den indruk van het oogenblik sprekend kunstenaar, dan kan men tot allerlei dwaze voorstellingen komen. Van dezelfde methode gebruik makende, zou ik met het grootste gemak den schrijver van Trijntje Cornelis en van de Sneldichten als den meest onkieschen, meest zedeloozen man van zijnen tijd kunnen voorstellen. En wie, die VONDEL alleen uit zijn hekeldichten kende, zou zich niet van zijn karakter als dichter en als mensch een geheel averechtsch 
denkbeeld vormen? Doch wie zou ook zulk eene wijze van beoordeeling goedkeuren? Stellig niemand, Dr. KoK in de eerste plaats niet. En daarom verwondert het mij wel eenigszins, dat deze, vooral na de aanduidingen hem door Dr. WORP en mij gegeven, het niet de moeite waard geacht heeft, dieper in zijn onderwerp door te dringen en in dit opzicht althans "den ganzen Menschen" te leeren kennen. Ik wil trachten, voor zoover de mij toegestane ruimte dit gedoogt, het door hem verzuimde te doen en vestig daarom allereerst de aandacht op een geschrift, dat ons omtrent HUYGENs' leven en denkwijze de zekerste inlichtingen geeft en dus door Dr. KoK stellig had moeten geraadpleegd worden. 't Is het overbekende: Const. HugenII De vita propria Sermonum inter liberos Libri duo, door HUYGENS op 83-jarigen ouderdom opgesteld, en dat, niet voor openbaarmaking bestemd, ons den dichter, gelijk DE GENESTET zegt „in huiselijk négligé", dus zoo natuurlijk en onopgesmukt mogelijk, voorstelt. Het heeft daarenboven de verdienste van later dagteekening te zijn dan alle door Dr. KoK geciteerde verzen en zou dus, als dat noodig ware, de er mede strijdige uitingen uit vroeger tijd te niet doen.

$\mathrm{Na}$ verteld te hebben, hoe zijn voortreffelijke vader hem in zijne jeugd in alle takken van wetenschap en kunst, liet onderrichten zegt hij, tot de schilderkunst komende (Vertaling v. LoosjEs, blz. 22):

\footnotetext{
De volle zuster der beminde Poezy,

De schoone schilderkunst sloeg nu haar oog op mij.

Hoe zal 'k die eedle kunst meer naar heur waarde roemen

Dan door eenvoudig haar de kunst van zien te noemen.

' $k$ Bestempel heur daarmede in d' eigenlijken zin,

$\mathrm{Zij}$ boezemt aan den mensch een geestbeschaving in,

Zoo groot, dat zij, die niets van haar beginsels weten,

Bij een beschaafd geslacht zelts blinden mogen heeten;

Ja blinden zijn zij, want de hemel, aarde en zee

Beschouwen ze ongeroerd, als 't redelooze vee,

Dat bukkend naar den grond, het gras scheert van de weiden,

En weten, 't geen zij zien, bezwaarlijk te onderscheiden.

Op d' omtrek van het schoon van houding, koloriet,

Van evenredigheên let hunne boerschheid niet.

De schilderij, met rook en oudheids stof betogen,

Heeft, hoe voortreflijk ook, geen waarde in zulker oogen,

Door wie, voor 't zaaklijk schoon der oude schilderbent

Verblind, de voorrang wordt den nieuwren toegekend.

' $t$ Is alles duisternis en nevel om hen henen,

Wijl zich de ervaarnen zien door middaggloed beschenen.

Dit wist mijn vader, dic, der Kunst niet ingewijd,

Verlangde, dat zijn kroost, door oefening en vlijt,

Zooveel ten minste van die schoone kunst zou leeren,

Als hen door brave liên van hunnen rang deed eeren,
} 
En zou doen deelen in de welverdiende gunst

Van kunstervaarnen en beoefenaars der kunst.

't Was Hondius, die mijne en 's broeders hand bestuurde, Die in ons jeugdig hart de zucht voor kunst ontvuurde. Schoon geen APPELles in ons schilderschool geacht, Ligt viel het schilders toch, ver boven hem in kracht En schitterend vernuft geprezen en verheven, Den kweekling onderwijs op hooger spoor te geven, Dien hij, bij de eerste schreên, bij d' aanvang van het pad, Een klaar en juist begrip der kunst geschonken had. In 't werk van GolTziUs, dat luisterrijk zal pralen, Zoolang aan 't luchtgewelf het licht der zon zal stralen, 't Welk zijn beroemde stift in duurzaam koper sneed, Werd mijne kunstvlijt, als een oefenschool, besteed, En ' $k$ poogde met de pen of krijt zijn spoor te drukken. Hoe ver ' $k$ ten achter bleef bij deze meesterstukken, ' $\mathrm{k}$ Beklom zoo hoog een' trap weldra in deze kunst, Dat ik, op 's vaders last, of zoo de losse gunst Der wankele fortuin mij daartoe had gedreven, En, zoo 't mijn af komst leed, dat kunstspoor op te streven, Niet in den laagsten rang der schilders waar' gesteld. Ik koos het miniatuur, wiens naam zijn soort vermeldt, Of ook het stippelwerk, of zocht door olieverven 't Gelaat van maag en vriend te hoeden voor versterven;

"Daar Pallas, niet gedost in 't krijgspantsier gehengt, Dat nu 't olijfsap met de verwe zich vermengt En dus de beelden, die de kunstpenseelen malen, Met onverwelkter jeugd en vaster luister pralen, Dan toen, in vroegere eeuw, de losse waterverf Het kunstwerk liet ter prooi van een te vroeg verderf. Ik maalde in 't miniatuur tafreeltjes aan de wanden

Van vriend en magen, ligt nog hier en daar voor handen.

Ik geef deze regels zonder commentaar, maar vraag aan Dr. KoK en iedereen, die ze leest, of de drie en tachtigjarige, welke ze schreef, iemand kan zijn, "wien het aan hart en oog voor de schilderkunst ontbreekt"?

Maar misschien is HuYGENs eerst op lateren leeftijd tot dit beter inzicht gekomen en was hij vroeger een andere zienswijze toegedaan?

Wat hij in het voorgaande over zijn eigen lust en aanleg voor de schilderkunst zegt, weerspreekt dit reeds voldoende, doch wij behoeven hiermede niet te volstaan en kunnen ook op een werk wijzen, dat aan de door Dr. KoK geciteerde verzen voorafgaat, daar het volgens Dr. WORP tusschen I629 en I63I, toen Huygens dus 35 à 36 jaar oud was, vervaardigd is en voor de kunstliefde en den kunstsmaak van den schrijver de onwraakbaarste getuigenis aflegt. Ik bedoel de eveneens in het latijn opgestelde autobiographie, waarvan Dr. WoRP in den Jaargang I89I, af. 2, van dit Tijdschrift gewag maakt, terwijl hij - gelukkig, voor ons doel - er dat gedeelte van publiceert, hetwelk op de schilderkunst 
betrekking heeft. Men leze of herleze het en zegge mij dan of een man, die zulk een kennis van de schilders uit zijnen tijd aan den dag legt en met zulke bewondering van DE Ghein, Goltzius, Rubbens, Lievens, Rembrandt, enz. spreekt, voor een minachter hunner kunst kan gehouden worden. Of uit zich geen geestdrift - ik kan mij niet weerhouden dit ééne citaat hier in te lasschen - in de volgende beoordeeling van REMBRANDTS schilderij, de berouwhebbende Fudas?:

„Laat geheel Italië hier komen en al wat van de hoogste oudheid af voor schoons en bewonderenswaardigs is overgebleven. Het gebaar van den wanhopigen JUDAS alleen, om nu niet te spreken van zoovele bewonderenswaardige figuren op dit ééne doek, van JUDAS, die raast, jammert, vergiffenis afsmeekt en haar toch niet verwacht of die verwachting op zijn gelaat uitdrukt, dat afschuwelijke gelaat, de uitgerukte haren, het gescheurde kleed, de gewrongen armen, de handen ten bloede toe geknepen, de knie door eene plotselinge beweging gebogen, het geheele lichaam ineengerold met een woestheid, die medelijden opwekt, die figuur stel ik tegenover elk kunstwerk van alle eeuwen en ik wensch, die onkundige menschen te kennen, die meenen - reeds elders kwam ik er tegen op - dat tegenwoordig niets kan worden gedaan of gezegd, wat niet reeds in de oudheid gezegd en gedaan is. Wart ik beweer, dat geen Protogenes, APELLES of PARRHaSIUS gedacht zou hebben, noch, als zij terugkwamen op aarde, zou kunnen denken aan datgene, wat - en ik sta verstomd, als ik het zeg - een jongmensch, een Nederlander, een molenaar, een baardelooze, al niet in ééne figuur heeft bijeengebracht en te zamen heeft uitgedrukt. Bravo, REMBRANDT! Het was van minder beteekenis Ilium en geheel Azië naar Italië over te hebben gebracht, dan dat de grootste roem van Griekenland en Italië door een Nederlander, die tot nu toe nauwelijks buiten de muren van zijn geboortestad is geweest, naar Nederland is overgeplant."

Hoe overtuigend intusschen een dergelijke ontboezeming ook moge wezen, Dr. KoK zou in zijn recht zijn met mij tegen te werpen: „Woorden, niets dan woorden! Tegenover deze uitingen, wier waarde ik niet ontken, waarop ik zelfs uitdrukkelijk heb gewezen, stel ik andere, die van het tegendeel getuigen."

Welnu, laten wij die andere dan ook even aan cen onderzoek onderwerpen; wij zullen zien, of zij de gevolgtrekkingen rechtvaardigen, die Dr. KoK er ten nadeele van HUYGFNs uit trekt, en daarbij de gelegenheid hebben ons te overtuigen, dat de laatste ook nog door iets anders dan door woorden bewijs geeft van zijne liefde voor de nobilissima ars.

Ik begin dan met de argumenten te toetsen, welke Dr. KoK in zijn laatste artikel (Noord en Zuid XVIII, 3) aanhaalt en die, terwijl zij hem aanleiding gaven op zijne herroeping terug te komen, hem zijn eindoordeel deden formuleeren in 
de volgende bewoordingen: „Wij staan hier letterlijk voor een zielkundig raadsel, dat alleen opgelost kan worden in den geest als BILDERDIJK deed, toen hij zeide: "HUYGENS' smakk voor de schilderkunst was slechts aangeromen, niet innig en eigen.","

Het eerste dezer zoogenaamde bewijsgronden is de volgende passage over schilders uit Huygens' merkwaardig gedicht: Oogentroost: ${ }^{1}$ )

De Schilders (dit gaet hoog) de Schilders, PARTHENINE, (Noch zijn ze van 't geslacht dat ick eerbiedigh diene) De Schilders heet ick blind, en, soo m' er wel op lett, 't $Z_{\mathrm{ij}}$ scheppers meestendeel: sy sien maer door 't palett En bouwen een' Natuer, die vriendlick is van wesen En soet en aengenaem: maer meent ghy daer te lesen Hoe Groote Moer Natuer haer eigen wesen staet? 't Is verre van den wegh. Een' steegh is oock een straet, Een hutt is oock een huys, en struyken zijn oock boomen, Maer steegh en hutt en struyck zijn schaduwen en droomen By straet en huys on boom: daer hoort veel guedheits toe Om Gods en menschen werck te keuren met gemoe Voor even en gelijck. Wat wil m' ons meenen leeren? Twee droppen zijn niet eens, twee eyeren, twee peeren, Twee aengesichten min: de trotste mogentheit

Van d' eerste Schepper blijckt in 't eewigh onderscheit Van all dat was en is en worden sal na desen;

$\mathrm{En}$ is 't laet-duncken van een mensch soo hoogh geresen, Dat menschen konnen, daertoc God, in allen schijn, Niet Kunstenaers genocgh, niet Scheppers wild: zijn? Siet hoe verr' 't soete volck in dese blintheit dwaelen: Gaet met haer wandelen door boom en bergh en daelen: Dat's, seggens', een gesicht dat Schilderachitig staet. 'k Kan 't niet ontschuldigen, 't is derteltjes gepraett: My dunckt sy seggen, God maeckt kunstige Copijen Van ons oorspronckelick, en mach sich wel verblijen In 't meesterlick patroon, al waer 't van onse hand, 't En kon niet schooner zijn, in Zee en Locht en Land. Gaet met die Scheppers thuys, en leent se 't strackste wesen 't Langhmoedigste geduld, om door en door te lesen Hoe God uw aensicht schiep: Als 't langh gemartelt is, Daer staet ghij in 't pancel : maer, in een woord, 't is mis: Sy scheppen U een Yet, een' Bloed-verwant, een' Broeder: Maer ghij en staet 'er niet, de Dochter is maer Moeder, ve Vader is maer Soon. En, soeckt ghy meer bewijs, Komt tot de tweede proef: daer 's 't weer een' ander' wijz', Een ander Bloed-verwant, een nieuwe Nicht geboren, En ghy in twyffelingh wie wysselickst verkoren, Siet nu de Menschen in haer oogeloosheit aen, Of ' $t$ volck is om Gods doen of misdoen aen te slaen.

1) Korenblocmen I, 27̂े vlg. 
Wanneer Dr. KoK uit "deze aaneenschakeling van dwaze beweringen", zooals hij ze gelieft te noemen, een bewijs wil putten voor zijne stelling, dan past hier vooral het spreekwoord, dat ik boven aanhaalde: "Geef mij een paar regels schrifts, enz." Hoe is het mogelijk, dat Dr. KOK de strekking van het geheele gedicht zoozeer heeft kunnen voorbijzien, dat hij uit bovenstaande regels zulk eene beschuldiging heeft kunnen distilleeren! De redeneering toch, waarop het stuk berust, is geene andere dan deze: „PARThenine (LuCretia van Trello) vrees toch niet zoo, Uwe oogen te verliezen, want in zeker opzicht zijn alle menschen blind." En dan volgt die lange lijst van oogeloozen, waaraan letterlijk niemand ontsnapt; wijzen en dwazen, krijgshelden en lafaards, ouden van dagen en jonge lieden, dansers, schilders, dichters lijden aan dezelfde kwaal volgens de half boertige, half ernstig gemeende voorstelling van HUYGENS. In plaats van hier lang te pleiten, kan ik niet beter doen dan naast de passage der Schilders die der Dichters te leggen; want daarmede valt de geheele argumentatie van Dr. KoK in het water ${ }^{1}$ ):

De Dichters zijn dicht blind: sy sien maer door het Rijm En geven 't op voor Konst: of Kiste-makers lijm, Lijm, die maer kleven kan, voor steken en voor schaven, Voor maet en regelen, den lof aan 't Ambacht gaven, Sy tasten blindelingh de swaerste saecken aen, En hopen, will het Rijm maer volgen, 't sal wel gaen: En will het Rijm niet voort, sy wenden 't van die wall af, Weer op een nieuwen boegh, en racckender so mall af, En wecr soo lam daer aen (en lam is av'rechts mall) Dat Reden endelick in 't rijmende gevall

Als in den lijm, verstickt. en siet eens waers' u slepen Sy selver wegh gesleept en lett eens waer sy schepen, En waer hacr ancker valt: sy munten 't op Japan, En drijven duysend myl van daer in Astracan; Dat zijn Piloten, dat zijn verre-siende luyden! Kan ick 't u krachtiger als met mijn selfs beduyden? ('t was tijd ick mij beklapt' en by de blinden bracht' Ghy hadt het al begost, ick voclden Uw gedacht): Ghedenckt waer ick begon, waer ick mijn schaetsen aenbond, Siet waer ick henen ben, en, soo ghy 't soo verstaen kont, Weet dat het lieve Rijm mijn lijmen heeft beleidt, En, waer ick uyt gerijmt, ick waer lang uyt-geseyt. Noch ben ick soo soct blind als een der mede--blinden, En beeld mijn' sotheid in, ghy sult mijn onder-winden Mijn' aller winden loop voor lijdelick aen sien. Wat seght ghy? ben ick nu soo blind niet als ick dien? Maer 't is Poëten slagh; sy konnen 't niet ontleggen, Sij sien geen schooner ey dan dat sy selver leggen: En dreight ze met de pley, ghy pijnight' er niet uyt Dat eenigh Dichter oyt haer luyt hebi' over-luydt.

1) Korenbloemen I, $287 \mathrm{vlg}$. 
Entweder - oder: Dr. KoK moet aan HuYGENS ook oog en hart voor de Dichtkunst ontzeggen - hij herleze dan echter eens de Print van Een algemeen Poëet - of erkennen, dat wat deze hier van de Schilders beweert, geen den minsten grond kan zijn voor het tot hem gericht verwijt. ${ }^{1}$ )

„Maar wij zijn er nog niet”, zegt Dr. KoK, en dan laat hij twee sneldichten volgen, die het door hem gestelde afdoende moeten bewijzen. Hier zijn ze:

'T ONKOSTELIEK MOY. $\left.{ }^{2}\right)$

'k Hou veel van schilderijen Die Oogh en Hert verblijen : En, schoon sy doen het niet; De Kunst is meer als yet, En kan mij zeer betreckken : Maer van die wijse gecken En ben ick niet, God lof, Die met den ecrsten bof Van 't niew daerhenen vallen, En 't reedste Geld vermallen Aen tuygh van veel min nood Als 't dagelicksche Brood. Hcbb ik my oyt verloopen In 't ongeduldigh koopen, Myn eerste straffe was, Ick voelde 't in mijn Tass : De tweede; dat dry maenden My leerden en vermaenden Wat onversiens begaen Veel beter waer ontdaen. Sott, seid' ick, blijft indachtigh, Waert ghy a selven machtigh, En noch die dicre Waer Aen d'eersten Eigenaer;
Gy soudtse met vermaken

Eens altemet genaken

En boeteu soo den lust

Die nu light uytgeblust.

Waer is 't Geld ondertusschen,

't Geld dat ghy gaeft van blusschen?

't Geld heeft de wyse mann,

Die 'r wijn voor koopen kan,

En $U$ heeft aengehangen

't Geen hy met versch verlangen

By wylen komt en siet

En 't sien en kost hem niet.

Daer ghy u het gevoelen

Voelt in 't besitt verkoelen,

En loopt uw' schildery

Meest blindelingh verbij

Daer gh' in het eerst vergapen

Scheent by te sullen slapen.

Is 't nu niet wel bestelt?

Uw niet sien kost u Geld.

Dit syn de sweepc-slagren

Die 'ck my heb leeren dragen,

Als ick na sott wierd satt

Siet voor u, die het vatt.

\section{NIET VOOR WAT, WAT VOOR NIET.}

Het soet Pinceelen-werck bemin ick van der jeughd,

En houd' het in den Mensch de nutste konst en deugd;

't Verganckelick becld der Schepselen te vesten,

Soo dat het met de Werld bestaen kan tot den lesten,

En toonen Kinderen, na menigh hondert Jaer,

Haer over, Over, en ver-over Groote Vaer,

En thoonen my de Werld haer' Landen en haer' Steden

Die 't noyt en is myn lot gevallen te betreden,

1) Nog overtuigender zou de aanhaling omtrent de masici zijn geweest, die er al even slecht afkomen, terwijl toch HUYGENs' smaak voor de muziek volgens BILDERdjk , innig en eigen" was.

2) Korenbloemen I, blz. 529. Het gedicht komt wel niet onder de eigenlijk gezegde Sneldichten voor, doch Dr. KoK zal toegeven, dat het daarvan evengoed het karakter draagt als bet onmiddellijk volgende. 
Der Schilders logenen en droomen by den dagh

Zyn oock moy dingetjes, die ' $k$ gecrne lyden magh,

En, mieer als lijden, veel en overveel kan achten:

Maer noyt en heeftmer my mijn' Bors om sien verkrachten.

De reden is, ick voel mijn' yverighsten Lust

Van 't geen' ick langh besit allengskens uytgeblust,

En vind mijn Ooge soo verbijstert door gewoonhcit

Als of het waer ont-ooght tot ongevoel van Scheonheit.

Maer brenght my in den Schat van Vrienden wel versien,

En gunt my daer somtijds met verscher oogh te sien

Wat ick voorhenen sagh en meer wensch te genaken;

Daer voel ick niewe vreughd, onafgetecrt vermaken,

Onafgesleten lust op al myn sinnen slaen;

$\mathrm{En}$, dat noch beter raeckt, daer 's geen betaelen aen,

De sackjens blyven toe, ick sie voor niet met allen

Wat thuys geld gelden sou. Waer' $t$ niet dolhuyslick mallen,

Gcld spillen binnens huys, voor wat men niet en siet,

In plaets van 't buyten wel te sien en geven niet?

Bij het eerste dezer twee gedichten roept Dr. Kok uit: "Gelukkig, Hurgens, dat er nog SIXEN en anderen waren onder uw tijdgenooten, die zich niet als gij onder de Wijzen rekenden, maar de beurs dorsten openen om een kunstwerk meester te worden. $\mathrm{Zij}$ verschilden in meening met den dichter van „Onkostelick Mooi" en dachten zooals KEATS uitdrukte in den welbekenden regel:

\section{A thing of Beauty is a joy for ever."}

Verder haalt hij met blijkbare instemming BILDERDIJKs aanteekening op dit gedichtje aan: „Kan de lust voor het schoone ooit uitgebluscht worden? Maar HUYGENS smaak voor schilderkunst was ook slechts aangenomen, niet, als dien hij voor de muziek had, innig en eigen. -- Wonderlijke zucht voor Schoon en Kunst inderdaad, waar men wijn voor verkiest."

En ook wat het tweede gedicht betreft, vereenigt hij zich met de volgende aanteekeningen van BILDERDIJK, terwijl hij zijne verbazing te kennen geeft, „dat deze zich niet nog krasser heeft uitgelaten bij een klaploopen van de ergste soort om eigen zak gesloten te houden."

„Bemin ick. Ja, gelijk de, boer een rijmtjen bemint. Maar Huygens heeft daarmee even zoo weinig besef van de Schilderkunst, als die boer van de Poëzy."

En bij een volgenden regel:

„Door gewoonheid - ongevoel van schoonheid. Bewijs, dat Huvgens alleen met het oog zag; de ziel wordt van 't schoon nooit verzadigd."

Ik geloof, dat Dr. KoK en BILDERDIJK een billijker oordeel over HuYGENS Oud-Holland i 896 . 
kuns'tliefde zouden hebben uitgesproken, wanneer zij zich 's Dichters regelen uit het Costelick $\mathrm{Mal}^{1}$ ) hadden te binnen gebracht:

O uer, plaets, en waerom, omstanders aller saken,

Die steets zijn gissingen op uw getij' can maken,

Wat leeft hy boven 't peyl van 't menschelick gemeen!

Beiden toch zien totaal over het hoofd, dat de beide stukjes Sneldichten zijn, d.w. z. plotseling invallende gedachten, opwellingen van 's dichters gril en luim, die nu eens in 't voordeel, dan weer in 't nadeel van de onderwerpen uitvallen, naar gelang van de stemming, waarin de Dichter verkeert, of het standpunt, waarvan hij die onderwerpen bekijkt. Hij zelf heeft aangegeven, hoe hij ze beschouwd wil hebben, die "boutades", waarin zijn speelsch vernuft zich vermeien gaat, nu eens puntig, scherp, dan dolkluchtig bij het droogkomieke af, dan weer met een tintje van diepen en weemoedigen ernst. Met enkele motto's, die hij eraan laat voorafgaan, teekent hij hunnen inhoud en tevens hun recht van bestaan op uitnemende wijze: Ik citeer er alleen het volgende uit:

"Lusus ${ }^{2}$ ) vocantur, sed hi lusus non minorem interdum gloriam quam seria consequuntur. Plinizis Sec. ep. I. 7."

en

Veracht mijn Sneldicht niet; 't is alchemistery,

't Is mergh van langhen sin; 'ck segh niet, hoeveel het weerdt is,

En of ' $t$ uyt goede stof of quâe gedistilleert is;

Maer, soeckt ghy sot of wijs ${ }^{3}$ ) in 't korte, soo leest my.

Bij zulk soort van gedichten nu, kan het niet alleen voorkomen, maar komt het bij Huygens herhaaldelijk voor, dat van hetzelfde onderwerp nu eens niets dan goeds, dan weer "pire que pendre"' wordt betoogd. Wil men een treffend bewijs? $\mathrm{Na}$ de twee sneldichten ") waarin hij tot ergernis van Dr. KoK „de beste

1) Korenbloemen I, 67 .

2) 't Is dus spel, kortswijl, geen ernstig werk.

3) Ik cursiveer.

4) Korenbloemen II, 5o.

SCHILDERIJ.

De beste Schilderij weet ick geen naem te geven,

Als een waenwatige verschaduwing van 't leven:

Wilt ghy haer deughd verstaen? treedt in den Sonneschijn,

En siet wat Schaduwen van 't schoonste leven zijn. Noch.

Geen levendigh penceel kan 't by het leven haelen Al kwam Apelles weer En hondert and're meer;

All menschen mymeringh, die niet en doen als dwaelen: Met reden noemen sij ' $t$ in 't hooge Duitsch-Land maelen. 
schilderij een waenwatige verschaduwing van 't leven" noemt en van't schilderen met den hem eigen trek tot woordspelingen getuigt, dat "sy' $t$ in 't hooge DuitschLand met recht "maelen" heeten, komen er twee andere voor op een Schip. In het eerste, waar hij bepeinst "hoe swack's menschen macht is en hoe oneindig Gods" steekt hij den draak met dit gewrocht van 's menschen hand; in het tweede, waar hij het vergelijkt met een gevlagd en gewimpeld „Haeghsche Joffers hoofd" klinkt het:

Maer de gelijckenis gaet over één zy mis :

Dat (dìt) moy en onnut, (dàt) moy en dienstigh is.

En springt het nu ook bij de voorafgaande Sneldichten niet in het oog, dat aan de schilderkunst slechts dan dwaasheid en waanwijsheid wordt verweten, wanneer zij zich met "het leven” d.i. de levende natuur wil vergelijken? En wat zou daartegen in te brengen zijn? Even weinig en evenveel als tegen de regels, waarin hij DANIËL SEGERS een ,bloemschepper onder God"' noemt en van dengene, die dezen vermaarden schilder wil evenaren, getuigt, dat hij „zich most vermeten, wat Natuur, die wijze vrouw, Niet onderstaan en derf." Al was het Impressionnisme in de $17^{\text {de }}$ eeuw ook nog niet uitgevonden, aan de Impressie gehoorzaamden de Dichters toen evengoed als thans.

Heb ik hierboven aangetoond, dat Dr. KoK de eigenaardige soort van gedichten over het hoofd ziet, waaruit hij zijne argumenten put, thans wensch ik er op te wijzen, dat hij de geheele persoonlijkheid van HuYGENs buiten beschouwing laat en nòch met den tijd, waarin deze leefde, nòch met het volk, waartoe hij behoorde, rekening houdt.

Vat ik Dr. KoK goed, dan heeft hij tegen Huygens' wijze van beschouwing in Onkostelick moy en Niet voor wat, wat woor niet, de volgende hoofdgrieven:

${ }^{0}$. dat de lust voor schilderijen, die zijn eigendom waren, bij HurGeNs langzamerhand bekoelde en zelfs werd uitgebluscht;

$2^{0}$. dat Huygens 't dwaasheid acht geld uit te geven voor kunststukken, waarvan hij de schoonheid bij anderen genieten kan, zonder dat het hem iets kostte.

Wat het eerste punt betreft, moet ik Dr. KoK er aan herinneren, dat HuYGENS als dichter op en top een moralist is, niet zoo saai en vervelend als de meesten onzer leerdichters, maar toch een moralist, d. i. „ein Verstandsmensch." Aan geestdrift geeft hij zich zelden over, integendeel hij waakt er angstvallig tegen. Brengt hem zijn onderwerp soms ondanks zich zelven in vervoering, onmiddelijk tracht hij weer de heerschappij over zijn gevoel te heroveren. $\mathrm{Na}$ 
die schoone opwekking tot mildheid b.v. in Costelick Mal, die tot bezielend lyrisme is overgegaan, klinkt het onmiddellijk: ${ }^{1}$ )

Hoe heb ick 't, waerde CATS, hoe raeck ick hier om hoogh?

Wat heeft my dus vervoert uyt aller ooghen oogh,

Daer d' oogen schemeren, daer wasch en wiecken smelten?

Of loert mij weer ter hand, of kortt my dese stelten;

Ick struyckel op het land, wat maeck ick in de lucht?

Het kruypen is my konst, wat maeck ick in de vlucht?

Van zoo iemand eene dithyrambe op welke kunst ook te verwachten, ware dwaasheid. $\mathrm{Zij}$, evengoed als de vulgairste onderwerpen, moet, als hem dat goeddunkt, de kapstok zijn, waaraan hij zijne zedelessen ophangt. Geen algemeen menschelijker eigenschap nu, dan die, welke in het oude adagium: "Varietas delectat" is opgesloten. HuYGENs wijst er bijna op iedere bladzijde op, dat

Dat overhands gedoen is menschelick vermaecken ${ }^{2}$ )

en dat

Verandren geeft vreughd en niet veranderen pijn $^{3}$ ).

Van deze hebbelijkheid is de dichter zelf niet vrij gebleven: hij erkent dat met beminnelijke openhartigheid in zijn Hofwijck. ${ }^{4}$ ) $\mathrm{Na}$ aldaar verteld te hebben, hoe het plan van dit buiten tusschen VAN CAMPEN, POST en hem zelven was besproken en vastgesteld, vervolgt hij:

Doe 't kind geboren was, hoe 't afliep met sijn' lueren,

Sijn swachtels en sijn wiegh, soud' hier wat langer dueren

Dan 't yemand lusten moght; en van die eerste jeughd

En smaken meestendeel maer ouderen de vreughd:

Vreughd, die de Niewigheit en Hoôp alleen doen leven,

Waer op volght ongevocl van wellust, doove plaegh,

Daer van ick (ick beken 't) myn kindsch gedeelte draegh.

Wanneer hem zoo iets ten opzichte van zijn geliefd Hofwijck, het troetelkind van zijn bouwlustigen, zoowel als van zijn dichtlievenden aard kon overkomen, waarom dan ook niet ten aanzien der schilderijen, die zijn eigendom waren? En, laat ons oprecht zijn, gaat het met ons allen anders? "A thing of beauty" moge een genot voor altijd zijn, wij zijn daarom niet ten allen tijde voor dat genieten geschikt en de frissche, scherpe, overweldigencle indruk, dien wij een eersten kecr van een kunstwerk ontvingen, ondergaan wij later zelden of nooit meer.

1) Korenblo:men I, 84.

2) Aldaar I, 420 .

3) Aldaar I, 87.

4) Aldaar I, 3r4. 
„Maar die philisterachtige klaplooperij dan, die er zich in verkneukelt, te genieten van een andermans "Costelick Mal”, terwijl zij zelve de hand op de zakken houdt, hoe die te verdedigen?"

Laat ik liever eens vragen, hoe die te rijmen met de wetenschap, dat Huygens niet alleen vele en, naar het schijnt, kostbare schilderijen bezat, ${ }^{1}$ ) dat hij zijn portret zoowel als dat van zijne vrouw en kinderen herhaaldelijk, o, a. door VAN Dyck, liet maken, maar dat hij zelfs van zijn huis op het Plein verschillende teekeningen in doorsnede en perspectief door P. POST liet vervaardigen, die vervolgens in koper deed graveeren en ze aan zijn vrieuden ten geschenke zond. Zou er soms ook eenige overdrijving kunnen schuilen in hetgeen HUYGENs in de boven geciteerde Sneldichten van zichzelven zegt en zou hij zich, gelijk ons dat allen wel eens gebeurt, hier niet zwarter voorstellen dan hij is? Zou het bij den man, die door zijne vorsten en vrienden in alles wat kunst en smaak betrof, als de bevoegdste beoordeelaar en de algemeene vraagbaak beschouwd werd, die bij het bouwen o. a. van de Oranjezaal, thans het Huis ten Bosch, met de ordonnantie van het decoratieve gedeelte en de daarmede verbonden onderhandelingen en correspondentiën met tal van schilders belast was, niet zaak zijn het bekende spreekwoord om te keeren en op de daden te letten, in plaats van op de woorden? Mij dunkt er bestaat alle reden toc, vooral wanneer die man van zich zelf getuigt: ${ }^{2}$ )

$$
\begin{aligned}
& \text { dat's een van mijn' gebreken, } \\
& \text { Mijn selven, witt en doel, uyt yver t'overspreken. }
\end{aligned}
$$

Doch met eene vergoelijking wil ik mij niet tevreden stellen: ik wil aantoonen, dat ook hier, mits men slechts den geheelen mensch en de tijdsomstandigheden, waarin hij leefde, nict uit het oog verliest, HUYGENS van de schilderkunst niet heeft „misseit.” Doch dan moet ik de zaak wat dieper ophalen.

- Men zou zich een geheel verkeerd denkbeeld vormen, wanneer men meende, dat onze zeventiende-eeuwers de kunst als eene roeping, als een levensdoel beschouwden. Daartoe was onze volksaard toen nog te nuchter, te practisch en waren de tijden te ernstig. Men was in de eerste plaats christen, burger, kostwinner voor zich en de zijnen, en zoo aan de plichten, die hieruit voortsproten, voldaan was, ja dan offerde men graag, heel graag aan de Muzen. Maar in 's hemels naam geen theorie van "l'art pour l'art"; doch ,ne quid nimis" en "utile dulci", het nuttige bij het aangename! Dit is zoo waar, dat zelfs een VONDEL, zeker degeen die, met REMBRANDT, destijds het meest nadert tot wat men thans

1) Schinkel, Nad. Lijzonderh. betr. Const. HuYGens bl. 8 I vlgg.

2) Ciuyswerck, vs. $4^{89} \mathrm{vlgg}$. 
een artisten-natuur zou noemen, volgens het getuigenis van $\operatorname{Dr}$. KALFF , de den Hollander aangeboren zucht voor het nuttige en leerzame soms als lood aan de vleugels hangt." ') Moet het ons dan van HuYGENs bevreemden, die als rechtzinnig Calvinist het zaaien van zijn „koren” op den Staatsakker, als de hem van God gestelde levenstaak, en het strooien zijner dicht,,bloemen" slechts als „bijslagh" van den eigenlijken oogst beschouwde, wanneer hij zich door zijn "heet gevoelen", d. i. door zijn hartstocht voor de kunst, nooit verder vervoeren liet, dan het voor een bemiddeld, maar niet overrijk burger, vader van vijf kinderen, wien hij eene behoorlijke positie in de maatschappij te waarborgen had, schikte en betaamde? Daarenboven had hij niet in de maatschappij zijner dagen, die maar al te zeer tot prachtlievendheid en verkwisting begon over te hellen, voorbeelden genoeg, die tegen het toegeven aan ongebreidelde kunstliefde waarschuwden? Zou voor hem, den wijsgeer-moralist, de les verloren zijn gegaan, die zijn vorstelijke buurman JOHAN MAURITS VAN NASSAU-SiEGEN, de steeds in geldelijke ongelegenheden verkeerende stichter van het Mauritshuis, hem in dit opzicht gaf? Volkomen vereenig ik mij dan ook met het zoo juiste gezegde van D. VEEGENS: „DiDeze (HUYGENS) was en bleef, hoe bouwlievend ook, een echt Hollander der zeventiende eeuw, die het zich zelf nimmer zou hebben vergeven, indien hij door het botvieren van een overigens onschuldige neiging het erfgoed zijner kinderen had aangetast." ") Wanneer Dr. KoK naar een sleutel zoekt voor het zielkundig raadsel in Huygens' kunst- en kunstenaarsbeschouwing, hier wordt hij hem aangeboden en wel door een man, die HuYGENS door en door kende en zijne beoordeeling op feiten grondde, niet door een BILDERDIJK, welke, in zijn geloof aan eigen onfeilbaarheid, bij de karakteriseering van historische personen vaak even aprioristisch te werk gaat, als in zijne taalbeschouwingen.

Hiermede meen ik te kunnen volstaan. Heb ik mij naar den eisch van mijne taak gekweten, dan zal mijn hooggeachte vriend ook in dit opzicht HuvGENS zijne liefde en waardeering niet langer behoeven te onthouden.

1) Zie Gids I896, Mei-nummer, bl. 254.

2) Hist. Stud., dl. I, r2o. 